\title{
SKRIPSI
}

\author{
Evaluasi Fungsi Ekologis Pada Taman-Taman Kota di Kota Bandung \\ Diajukan untuk Memenuhi Syarat Mendapat Gelar Sarjana di Program Studi \\ Pendidikan Geografi \\ Fakultas Pendidikan Ilmu Pengetahuan Sosial
}

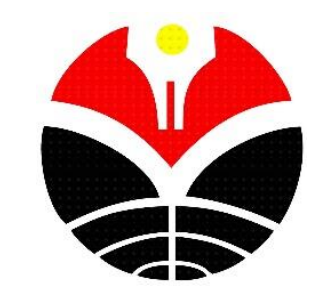

Disusun oleh

Rani Renita

1605749

PROGRAM STUDI PENDIDIKAN GEOGRAFI

FAKULTAS PENDIDIKAN ILMU PENGETAHUAN SOSIAL

UNIVERSITAS PENDIDIKAN INDONESIA

BANDUNG

2020 


\section{Evaluasi Fungsi Ekologis Pada Taman-Taman Kota di Kota Bandung}

Oleh

Rani Renita

1605749

Sebuah skripsi yang di ajukan untuk memenuhi syarat memperoleh gelar Sarajana Program Studi Pendidikan Geografi

(C) Rani Renita

Universitas Pendidikan Indonesia

2020

Hak cipta dilindungi undang-undang

Skripsi ini tidak boleh di perbanyak seluruhnya, atau sebagian, dengan di cetak ulang, di fotokopi, atau cara lainnya tanpa izin penulis 


\title{
LEMBAR PENGESAHAN
}

\author{
RANI RENITA
}

\section{EVALUASI FUNGSI EKOLOGIS PADA TAMAN-TAMAN KOTA DI KOTA BANDUNG}

disetujui dan disahkan oleh pembimbing :

\section{Pembimbing 1}

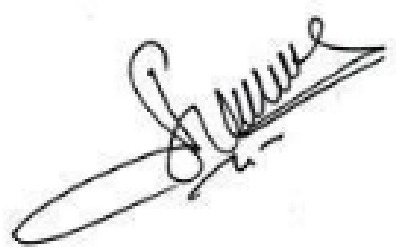

Dr. Iwan Setiawan,S.Pd,M.Si

NIP 197106041999031002

Pembimbing 2

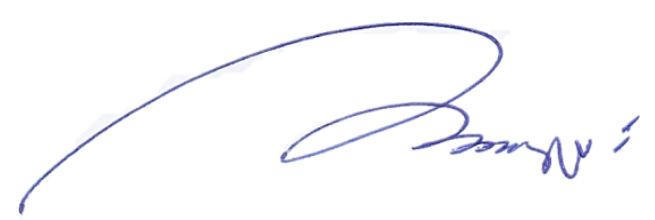

Dr.rer.nat Nandi, S.Pd., M.T., M.Sc

NIP 197901012005011002

Mengetahui

Ketua Departemen Pendidikan Geografi

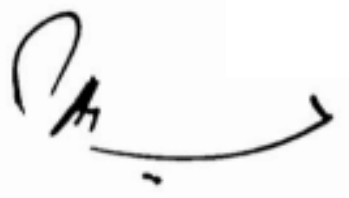

Dr. Ahmad Yani,M.Si.

NIP 197901012005011002 


\section{PERNYATAAN}

Saya menyatakan bahwa skripsi yang beryjudl "EVALUASI FUNGSI BROLOGIS PADA TAMAN-TAMAN KOTA DI KO'TA BANDUNG" inl sepenthnya karya sendiri. Tidak ada didalamnya yang merupakan plagiat dari karya orang lain dan Saya tidak melakukan penjiplakan atau pengutipan dengan cara yang tidak sesuai dengan etika kcilmuan yang berlaku dalam masyrakat. Atas pernytaun ini, saya siap menanggung resiko/sanksi yang dijatuhkan kepada saya apabila kemudian ditemukan adanya pelanggaran etika keilmuan dalam karya sayn ini, atau ada klaim dari pihak lain terhadap keaslian karya saya ini.

Bandung, Agustus 2020

Yang Membuat Pernyataan

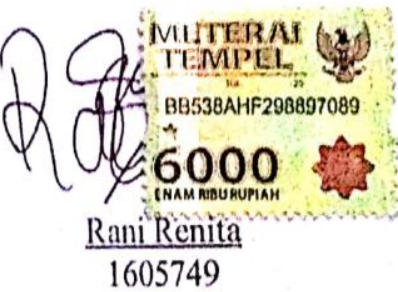




\section{KATA PENGANTAR}

\section{Bismillahirrahmannirrohim}

Dengan mengucapkan puji dan syukur kehadirat Allah SWT, yang telah melimpahkan rahmat dan hidayah-NYA sehingga memberikan dorongan dan kekuatan kepada penulis sehingga mampu menyelesaikan skripsi dengan judul "Evaluasi Fungsi Ekologis Pada Taman-Taman Kota di Kota Bandung" sebagai syarat memperoleh gelar sarjana dalam bidang Pendidikan Geografi.

Skripsi ini membahas efektivitas berjalannya fungsi ekologis pada taman-taman kota di kota bandung. Mengingat bahwa fungsi utama taman kota ialah fungsi ekologis sudah seharusnya pendirian taman kota mengedepankan sisi ekologis sebagai upaya penyeimbang kualitas lingkungan perkotaan. Oleh karena itu penulis memilih mengevaluasi masalah tersebut untuk diangkat dan dibahas sebagai topik penelitian.

Penulis menyadari penulisan skripsi ini jauh dari sempurna, hal ini dikarenakan keterbatasan dan kemampuan penulis. Penulis berharap dengan dilakukannya penelitian ini banyak manfaat yang dapat diambil dan dirasakan oleh berbagai pihak. Kritik dan saran yang membangun sangat penulis harapkan guna memperbaiki kualitas penulis. Penulis mengucapkan terima kasih kepada seluruh pihak yang telah turut bekerja sama dalam terselesaikannya skripsi ini.

Bandung, Agustus 2020

$\underline{\text { Rani Renita }}$

NIM 1605749

Rani Renita, 2020 


\section{UCAPAN TERIMAKASIH}

Penulis mengucapkan puji dan syukur kepada Allah SWT yang telah melimpahkan rahmat dan karunia-NYA sehingga penulis dapat menyelesaikan skripsi ini. Skripsi ini tidak mungkin terwujud tanpa adanya dukungan dan do'a dari berbagai pihak. Penulis juga mengucapkan banyak terikasih kepada:

1. Kedua orang tua penulis, Bapak Ramdhan Solih dan Ibu Yuyu Yuliani beserta keluarga besar yang selalu memberikan do'a dan dukungan untuk setiap langkah menuju kesuksesan

2. Dr. Iwan Setiawan,S.Pd,M.Si. selaku pembimbing 1 yang telah mengarahkan, dan selalu sabar dalam meluangkan waktu, tenaga dan pikirannya untuk membimbing penulis dalam penyusunan skripsi.

3. Dr.rer.nat Nandi, S.Pd.,M.T.,M.Sc. selaku pembimbing 2 yang telah mengarahkan dan membimbing hingga penulis dapat menyelesaikan penyusunan skripsi.

4. Dr. Ahmad Yani, M.Si selaku ketua Departemen Pendidikan Geografi, Seluruh Dosen dan serta staff Prodi yang telah memberikan banyak ilmu dan kelancaran selama menempuh perkuliahan.

5. Bapak Hadi Moelyono selaku Kepala Seksi Bidang Permukiman di DPKP3 Kota Bandung yang telah memberikan berbagai informasi membantu mensukseskan penelitian.

6. Teruntuk Upi, Sintya, Anggy, Widia, Gita, Ayu, Nafia, Nisa, Mule, Acil, Bejo, Obet, dan Abah, yang telah setia membantu langsung di lapangan tanpa kalian semua data tidak bisa diambil secara bersamaan.

7. Teruntuk sahabat-sahabatku (Upi, Tya, Frizka, Jeje dan Leni), teman-temanku dan teman-teman relawanku yang senantiasa mau diajak diskusi dan menemani dalam proses penyelesaian skripsi ini. Kemudian Teh Cindy, Kang Randi dan Kang Febrian yang memberi dukungan di momen kruisial.

8. Teman-teman Pendidikan Geografi angakatan 2016 yang telah memberikan dukungan dan bekerja sama dalam menyelesaikan perkuliahan.

Akhir kata peneliti ucapkan terimakasih banyak kepada semua pihakyang tidak dapat peneliti ucapkan satu-satu. Semoga dukungan dan bantuan tersebut menjadi berkah bagi semua pihak yang telah membantu hingga skripsi ini dapat terselesaikan.

Bandung, Agustus 2020

Rani Renita

NIM 16057

Rani Renita, 2020

EVALUASI FUNGSI EKOLOGIS PADA TAMAN-TAMAN KOTA DI KOTA BANDUNG

Universitas Pendidikan Indonesia | repository.upi.edu | perpustakaan.upi.edu 


\title{
EVALUASI FUNGSI EKOLOGIS PADA TAMAN-TAMAN DI KOTA BANDUNG
}

\section{RANI RENITA \\ 1605749}

\begin{abstract}
ABSTRAK
Taman kota memeiliki fungsi utama yaitu fungsi ekologis. Taman kota dikatakan berfungsi ekologis ketika mampu membentuk keseimbangan lingkungan perkotaan dan kondisinya dapat dirasakan oleh pengunjung. Tiga taman kota di Kota Bandung, antara lain Taman Balai Kota, Taman Tegallega, dan Taman Alun-alun. Ketiga taman tersebut menunjukan pergeseran fungsi yang seharusnya mengedepankan fungsi ekologis justru lebih menonjolkan fungsi estetis dan fungsi ekonomis. Penelitian ini bertujuan untuk mengevaluasi fungsi ekologis dari aspek vegetasi dan klimatologis dan mengetahui persepsi pengunjung tentang kondisi taman-taman kota di Kota Bandung. Metode dari penelitian ini kuantitatif dengan pendekatan deskriptif yang menggambarkan keadaan sebenarnya dari kondisi taman kota yang diteliti. Hasil penilaian fungsi ekologis menunjukan bahwa taman-taman kota di Kota Bandung memiliki kondisi vegetasi yang beragam, jumlahnya banyak, ketinggian didominasi 7-12 meter, memiliki daun lebar yang mampu memberikan naungan namun pohon yang berada di dalam taman kota hanya mampu menurunkan suhu $1.9 \mathrm{oC}$ belum memenuhi kriteria menurunkan suhu sampai $3-4{ }^{\circ} \mathrm{C}$. Kondisi Klimatologis memiliki rata-rata suhu udara $28.3{ }^{\circ} \mathrm{C}$ dan kelembaban udara memiliki rata-rata $57 \%$ yang artinya keduanya memenuhi kondisi ideal pada taman kota. Dari penilaian keseluruhan kriteria fungsi ekologis sebesar mencapai $75 \%$ yang artinya kondisi vegetasi dan klimatologis berperan dengan baik dan pengunjung berpendapat bahwa taman-taman kota dalam kondisi baik untuk memberikan keamanan dan kenyamanan saat berkunjung. Perlu adanya penambahan varietas tanaman yang ditanam secara menyebar dan merata agar peran tanaman bekerja lebih optimal.
\end{abstract}

Kata kunci : Fungsi Ekologis, Taman kota, Vegetasi, Klimatologis, Pengunjung

Rani Renita, 2020 


\title{
THE EVALUATION OF ECOLOGICAL FUNCTION OF CITY PARKS IN BANDUNG
}

\section{RANI RENITA \\ 1605749}

\begin{abstract}
Main purpose of city parks is to function ecologically. City parks were considered to be ecologically functional when they are able to create balance in urban environment and this function can be felt prominently by visitors. This research is focused on to three city parks in Bandung which are Taman Balai Kota, Taman Tegallega, and Taman Alun-alun. These three parks show changes in purposes to rather for aesthetic and economy. This research aimed to evaluate those parks ecological function from vegetation aspect, climatology, and to know how visitors perceive each park's condition. Quantitative method with descriptive approach is used for this research to capture the actual condition of these parks. Results from ecological assessment shows that parks in Bandung have various vegetation in numerous amount, their heights are around 7-12 meters, have large and wide foliage that can act as canopy. For the trees, they can only decrease the temperature to $1.9{ }^{\circ} \mathrm{C}$ and has not meet the required temperature which is $3-4 \mathrm{oC}$. As for climatological condition, these parks have average temperature of $28.3{ }^{\circ} \mathrm{C}$ with average humidity of $57 \%$ which are ideal for city parks. From overall assessment, the result for the ecological function is $75 \%$ which means these parks has good vegetation and climatologically helpful and were felt comfortable by visitors. Addition of plants varieties is needed and they need to be evenly planted for more optimal result.
\end{abstract}

Keywords: Ecological Function, City Park, Vegetation, Climatology, Visitor

Rani Renita, 2020

EVALUASI FUNGSI EKOLOGIS PADA TAMAN-TAMAN KOTA DI KOTA BANDUNG

Universitas Pendidikan Indonesia | repository.upi.edu | perpustakaan.upi.edu 


\section{DAFTAR ISI}

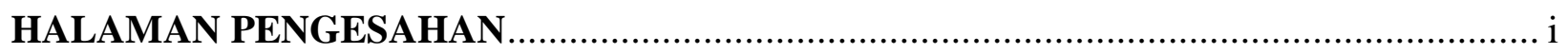

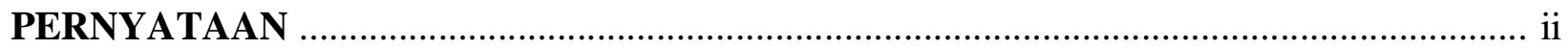

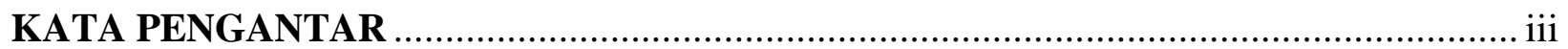

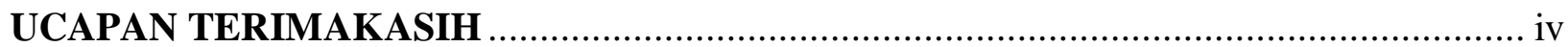

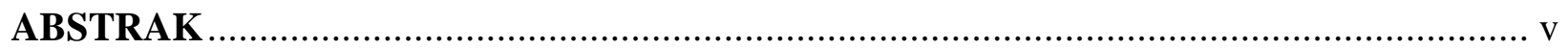

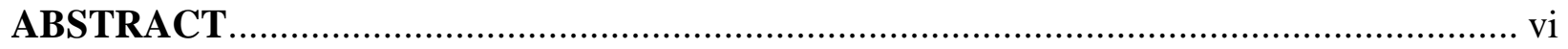

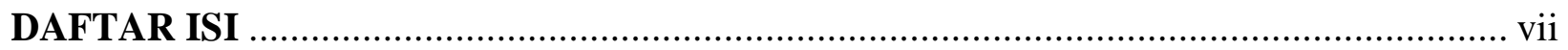

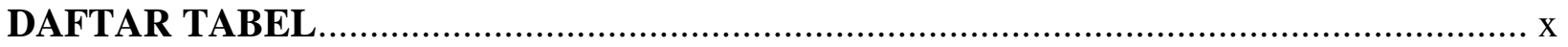

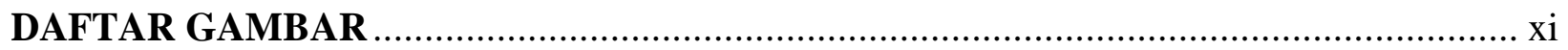

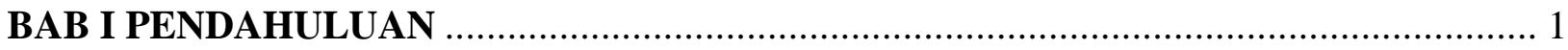

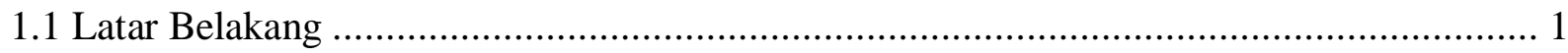

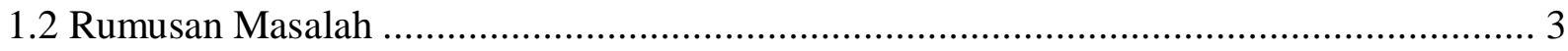

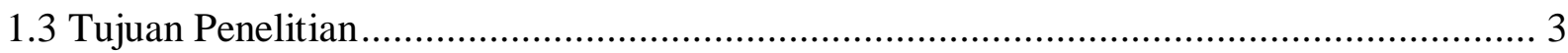

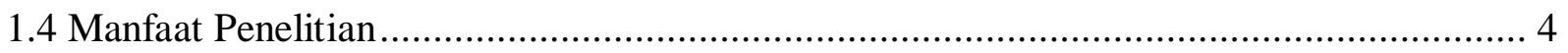

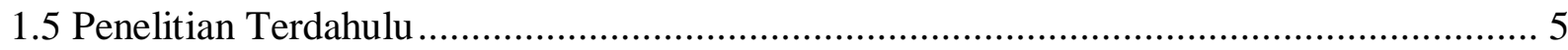

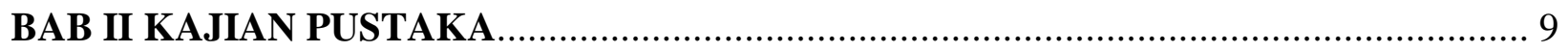

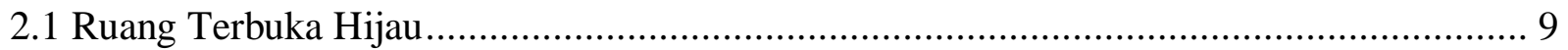

2.1.1 Tujuan Ruang Terbuka Hijau ............................................................................... 9

2.1.2 Fungsi Ruang Terbuka Hijau .............................................................................11

2.1.3 Manfaat Ruang Terbuka Hijau .............................................................................

2.1.4 Bentuk dan Jenis Ruang Terbuka Hijau ...........................................................15

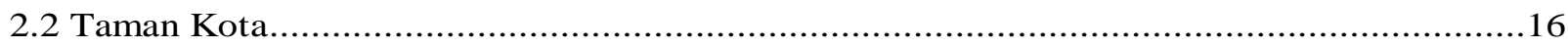

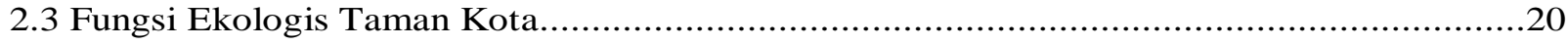

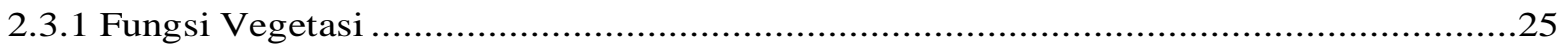

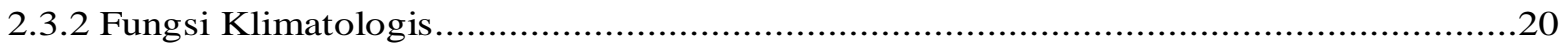

2.4 Persepsi Pengunjung Taman Kota....................................................................................27

Rani Renita, 2020

EVALUASI FUNGSI EKOLOGIS PADA TAMAN-TAMAN KOTA DI KOTA BANDUNG

Universitas Pendidikan Indonesia | repository.upi.edu | perpustakaan.upi.edu 


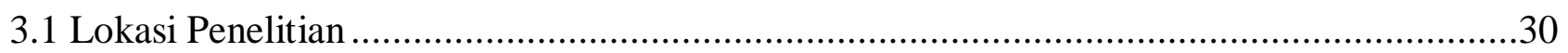

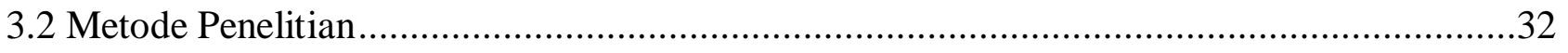

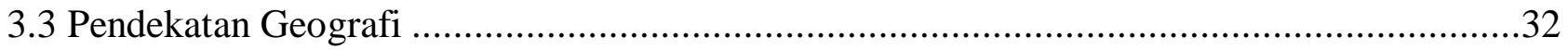

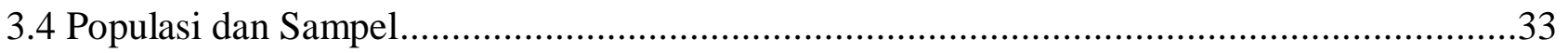

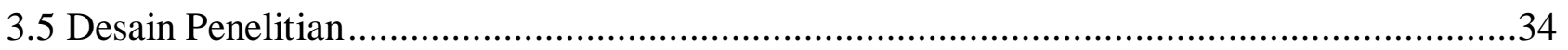

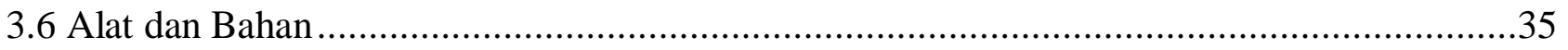

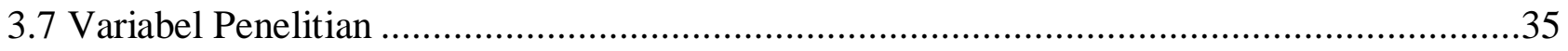

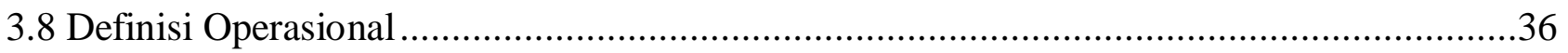

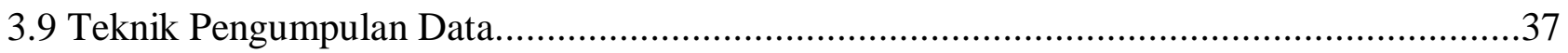

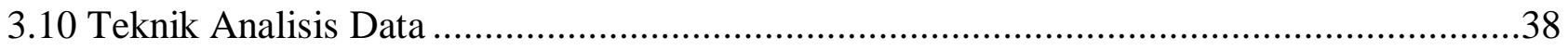

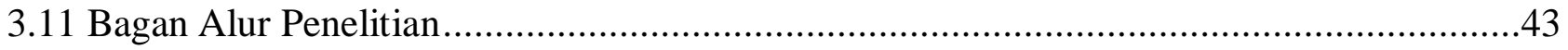

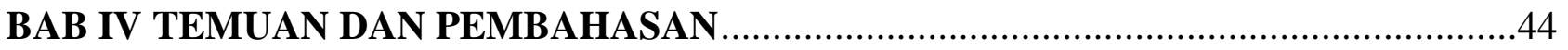

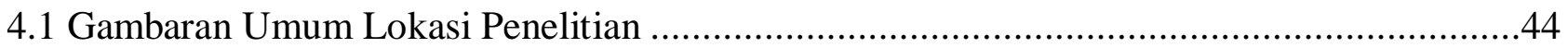

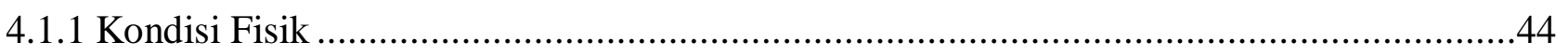

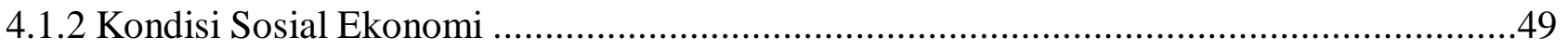

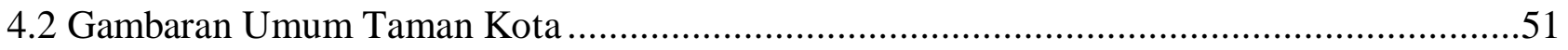

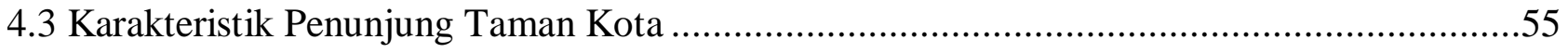

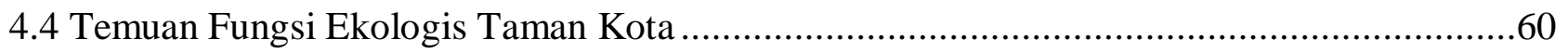

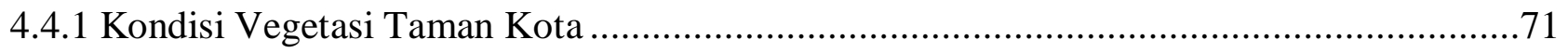

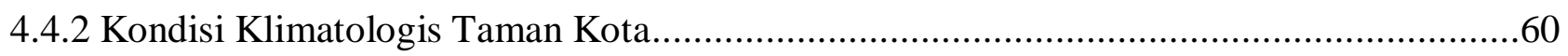

4.4.3 Persepsi Pengunjung Tentang Kondisi Taman Kota .......................................................79

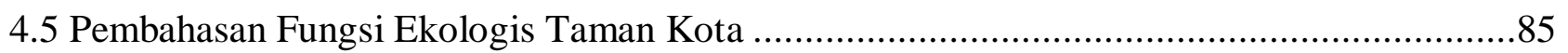


4.5.1 Kondisi Vegetasi Taman Kota ...................................................................95

4.5.2 Kondisi Klimatologis Taman Kota...................................................................86

4.5.3 Persepsi Pengunjung Tentang Kondisi Taman Kota ...........................................95

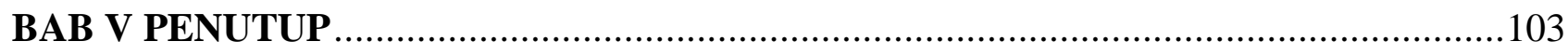

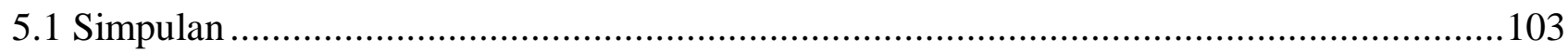

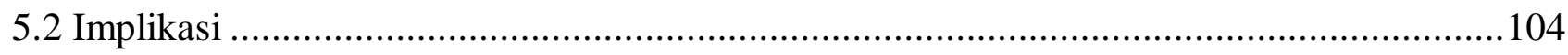

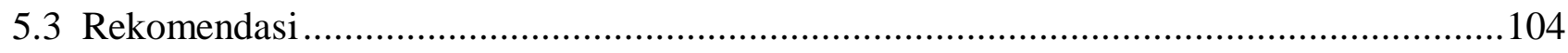

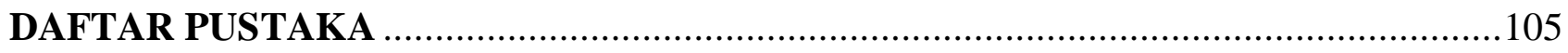

LAMPIRAN 


\section{DAFTAR TABEL}

Tabel 1.1 Review Penelitian Terdahulu ............................................................................ 5

Tabel 2.1 Fungsi dan Penerapan RTH Pada Beberapa Tipologi Kawasan Perkotaan .......... 13

Tabel 2.2 Kelengkapan Fasilitas Pada Taman Kota .......................................................... 19

Tabel 2.3 Kondisi Taman Kota .................................................................................... 20

Tabel 2.4 Contoh Pohon Untuk Taman Lingkungan dan Taman Kota ............................... 23

Tabel 2.5 Hasil Tumbuh-Tumbuhan Sebagai Peningkatan Kualitas Lingkungan Kota ........ 25

Tabel 2.6 Pembagian Jenis Tanaman .................................................................................... 25

Tabel 3.1 Daftar Taman Kota di Kota Bandung ............................................................... 33

Tabel 3.2 Variabel dan Indikator Penelitian ................................................................... 36

Tabel 3.3 Nilai Klasifikasi Fungsi Ekologis ....................................................................... 41

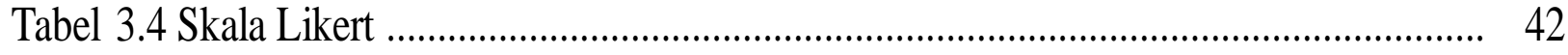

Tabel 4.1 Penggunaan Lahan Kota Bandung ………………………………………....... 46

Tabel 4.2 Jumlah Penduduk dan Laju Pertumbuhan Penduduk Kota Bandung .................... 50

Tabel 4.3 Distribusi PDRB Tahun 2017 \& 2018 ................................................................ 51

Tabel 4.4 Jenis Vegetasi Taman Balai Kota ....................................................................... 62

Tabel 4.5 Hasil Kemampuan Pohon Dalam Menurunkan Suhu Udara................................... 64

Tabel 4.6 Rekapitulasi Kondisi Vegetasi Taman Balai Kota ................................................ 65

Tabel 4.7 Jenis Vegetasi Taman Tegallega ..................................................................... 65

Tabel 4.8 Hasil Kemampuan Pohon Dalam Menurunkan Suhu Udara Taman Tegallega... $\quad 68$

Tabel 4.9 Rekapitulasi Kondisi Vegetasi Taman Tegallega .............................................. $\quad 69$

Tabel 4.10 Jenis Vegetasi Taman Alun-alun ................................................................... 69

Tabel 4.11 Hasil Kemampuan Pohon Dalam Menurunkan Suhu Udara Taman Alun-alun... 71

Tabel 4.12 Rekapitulasi Kondisi Vegetasi Taman Alun-alun ............................................. 71

Tabel 4.13 Kondisi Keamanan (Comfort) Taman Balai Kota ............................................... 80 


\section{DAFTAR GAMBAR}

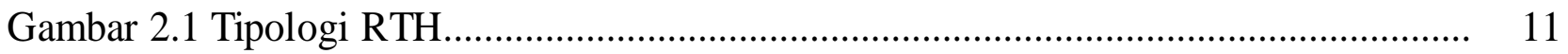

Gambar 3.1 Peta Persebaran Taman Kota di Kota Bandung ............................................... 31

Gambar 3.2 Alur Penelitian ..................................................................................... 44

Gambar 4.1 Peta Topografi Kota Bandung ……….......................................................... 47

Gambar 4.2 Peta Geologi Kota Bandung ..................................................................... 48

Gambar 4.3 Peta Pengunaan Lahan Kota Bandung …........................................................... 49

Gambar 4.4 Taman Balai Kota Bandung ........................................................................ 52

Gambar 4.5 Penutup Lahan Taman Balai Kota …………..................................................... 53

Gambar 4.6 Taman Tegallega ....................................................................................... 54

Gambar 4.7 Penutup Lahan Taman Tegallega ................................................................... 54

Gambar 4.8 Taman Alun-alun ................................................................................... $\quad 55$

Gambar 4.9 Grafik Pengukuran Suhu Udara Taman Balai Kota ........................................ 72

Gambar 4.10 Grafik Pengukuran Kelembaban Udara Taman Balai Kota ............................ 73

Gambar 4.11 Grafik Pengukuran Suhu Udara Taman Tegallega ........................................ 74

Gambar 4.12 Grafik Pengukuran Kelembaban Udara Taman Tegallega ............................. 76

Gambar 4.13 Grafik Pengukuran Suhu Udara Taman Alun-alun ........................................ 77

Gambar 4.14 Grafik Pengukuran Kelembaban Udara Taman Alun-alun .............................. 78

Gambar 4.15 Stratifikasi Vegetasi Taman Balai Kota ....................................................... 88

Gambar 4.16 Peta Kerapatan Vegetasi Taman Balai Kota ................................................... 89

Gambar 4.17 Stratifikasi Vegetasi Taman Tegallega ............................................................ 90

Gambar 4.18 Peta Kerapatan Vegetasi Taman Tegallega ................................................... 92

Gambar 4.19 Peta Kerapatan Vegetasi Taman Alun-alun ................................................... 94 


\section{DAFTAR PUSTAKA}

Anonim. (1996). Visi Misi Metropolitan Bandung 2020. Pemerintah Kotamadya II Bandung.

BPLH Kota Bandung. (2014). Pohon di Taman Kota Bandung. Bandung: Badan Pengelola Lingkungan Hidup Kota Bandung.

Brooks, R. G. (1988). Site Planning: Evaluation, Process, and Development. New Jersey : Prentice Hall. 322p. Tersedia: Pirka Setiawati. 2012. "Pengaruh Ruang Terbuka Hijau Terhadap Iklim Mikro (Studi Kasus Kebun Raya Cibodas, Cianjur)” . Institut Pertanian Bogor.

Car, S. (1993). Public Space Envirotment and Behavior Binding. New York: Cambridge University Press.

Carmona, M., De Magalhaes, C., \& Hammond, L. (2008). Public Space The Management Dimension. New York: Routledge Press.

Carpenter PL, Walker TD, and Lanphear FO. (1975). Plants in The Landscape. San Fransisco (ID): W. H. Freeman and Co. 481 p. Tersedia: Widyastuti Utami. 2013. "Studi Keragaman Dan Fungsi Ekologis Pohon Pada Lanskap Perkampungan Budaya Betawi Setu Babakan, Srengseng Sawah, Jagakarsa, Jakarta Selatan”. Jurusan Arsitektur Lanskap, Institut Pertanian Bogor.

Darmawan, E. (2009). Ruang Publik Dalam Arsitektur Kota. Semarang: Badan Penerbit Universitas Dipengoro

De La Barrera, F., \& Henríquez, C. (2017). Monitoring the Change in Urban Vegetation in 13 Chilean Cities Located in a Rainfall Gradient. What is the Contribution of the Widespread Creation of New Urban Parks? IOP Conference Series: Materials Science and Engineering, 245. https://doi.org/10.1088/1757-899X/245/7/072023. Tersedia: Aji

Uhfatun Muzdalifah "Kajian Indeks Vegetasi Pada Taman Kota Semarang Dengan Pemanfaatan Citra Landsat”. Tesis. 2019. Universitas Diponegoro.

Dinas Pemakaman dan Pertamanan Kota Bandung, (2016). Profil Taman Konservasi Tegallega. Frick, H. Feriadi, H. (2008). Atap Bertanaman ekologis dan fungsional. Yogyakarta: Kanisius Frick, H. Mulyani, T H. (2006). Arsitektur Ekologis. Yogyakarta: Kanisius 
Gates, D. M. (1972). Man and His Enviroment: Climate. New York: Harper and Row. 175p. Tersedia : Pirka Setiawati. 2012. "Pengaruh Ruang Terbuka Hijau Terhadap Iklim Mikro (Studi Kasus Kebun Raya Cibodas, Cianjur)” . Jurusan Arsitektur Lanskap, Institut Pertanian Bogor.

Hakim, R (1991). Komponen Perancangan Arsitektur Lansekap. Jakarta: Bumi Aksara Hardani. (2020). Metode Penelitian Kualitatif \& Kuantitatif. Yogyakarta: Pustaka Ilmu

Hashimoto H, Natuhara Y, Morimoto Y. 2005. A habitat model for Parusmajor minor using a logistic regression model for the urban area of Osaka, Japan. Landscape and Urban Planning 70 (3-4): 245-250

Katam, S. (2006). Bandung; Kilas Peristiwa di Mata Filatelis, Sebuah Wisata Sejarah. Bandung: Kiblat Buku Utama.

Katam, S. (2014). Gemeente huis (Balaikota) Bandung dan sekitarnya dari masa ke masa : Bandung baheula jeung kiwari. bandung: Kiblat Buku Utama.

Kolcaba, K. (2003). Comfort theory and practice: a vision for holistic health care and research. New York: Springer Publishing Company. Tersedia: Bambang Suyono, Eddy Prianto. Jurnal 2017. "Kajian Sensasi Kenyamanan Termal Dan Konsumsi Energi Di Taman Srigunting Kota Lama Semarang”. Departemen Aristektur. Universitas Dipenegoro.

Lakitan, B. (1994). Dasar-dasar Klimatologi. Jakarta: Raja Grafindo Persada.

Laurie, M. (1986). Pengantar Kepada Arsitektur Pertamanan. Bandung: PT. Intermatra Lippsmeier,G. (1994). Tropenbau Building in the Tropics, Bangunan Tropis (terj.)Jakarta: Erlangga.

Mardalis. (1999). Metode Penelitian Suatu Pendektan Proposal. Jakarta: PT Bumi Aksara

Margono. (2004). Metodologi Penelitian Pendidikan. Jakarta: Rineka Cipta.

Miller, R W. (1981) Urban Forestry. California: Wadsworth Publishing, Belmont. Tersedia: Heri Sulistyanto. Skripsi. 2017 “Pemanfaatan Dan Penyediaan Ruang Terbuka Hijau Untuk Mengurangi Pencemaran Udara”. Universitas Pasundan.

Nazaruddin. (1994). Penghijauan Kota. Jakarta : Penebar Swadaya

Prasetyo, Bambang, Lina Miftahul Jannah. (2008). Metode Penelitian Kuantitatif: Teori dan Aplikasi. Jakarta: PT Raja Grafindo Persada.

Project for Public Space, (2000). How to Turn a Place Around: A Handbook for Creating Successful Public Spaces. New York: PPS. Tersedia Carmona, M., De Magalhaes, C., \&

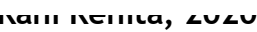


Hammond, L. (2008). Public Space The Management Dimension. New York: Routledge Press.

Ridwan. (2004). Metode Penelitian Survei. Jakarta : Pustaka LP3ES

Rusmayadi, G. (2013). IklimMikro; Teori, Pengukuran dan Analisis.Banjarmasin: P3AI Universitas Lambung .

Sarwono, S. (1999). Psikologi sosial: Individu dan Teori-teori Psikologi Sosial.Jakarta: Balai Pustaka. Tersdia : Sasongko, P.D.(2002). Kajian Perubahan Fungsi Taman Kota di Kota Semarang. Universitas Diponegoro

Wulandari LD, Rachmawati TA, Ramdlani S. 2013. Hirarki peran ragam ruang terbuka hijau (rth) dalam peningkatan kualitas ekologis lingkungan pusat Kota Malang [Laporan Akhir PUPT]. Malang: Universitas Brawijaya.

Simond, J.O. Landscape Architecture, Mc Grow-Hill Book Co. New York, (1984). Tersedia : Iman Harwafi, Tugas Akhir 2013. "Kajian Konsep Pengembangan "Green Corridor" dalam rangka menanggulangi pencemaran udara akibat kendaraan bermotor pada koridor jalan buah batu Kota Bandung”. Jurusan Teknik Planologi, Universitas Pasundan.

Sulistyantara, B. (1992). Taman Rumah Tinggal. Bogor: Penebar Swadaya

Tanudidjaja, (1993). Ilmu Pengetahuan Bumi dan Antariksa. Jakarta : Penerbit Departemen Pendidikan dan Kebudayaan.

Tika, P. (2005). Metode Penelitian Geografi. Jakarta: PT. Bumi Aksara.

Tjasyono, B. (2004). Klimatologi. Bandung: ITB

Jurnal \& Artikel

Abreu-Harbich., Labaki, L C., Matzarakis, A. (2015). Effect of Tree Planting Desaign and Tree Spesiec On Human Thermal Comfort In The Tropics. https://www.urbanclimate.net/matzarakis/papers/lup_2015_loyde.pdf

Ardiansyah, A. (2012). Public Space Ditinjau Dari Fungsi Ekologi Dan Estetis (Studi Kasus Taman Cibeunying Kota Bandung). Universitas Pendidikan Indonesia

Badan Pusat Statitika. (2019). Kota Bandung Dalam Angka Tahun 2019. Badan Pusat Statistika Kota Bandung

Cahya, D L., Widyawati, Laili F., Ayodhia., Fazhar W. (2016). Evaluasi Ketersediaan Ruang Terbuka Hijau Di Kota Bekasi. Universitas Esa Unggul

Rani Renita, 2020

EVALUASI FUNGSI EKOLOGIS PADA TAMAN-TAMAN KOTA DI KOTA BANDUNG

Universitas Pendidikan Indonesia | repository.upi.edu | perpustakaan.upi.edu 
Ernawati, R. (2015). Optimalisasi Fungsi Ekologis Ruang Terbuka Hijau Publik di Kota Surabaya. EMARA Indonesian Journal of Architecture Vol 1 Nomor 2 - Desember 2015 ISSN 2460-7878, e-ISSN 2477-5975.

Ningrum, E. (2006). Tempat, Ruang dan Sistem Sosial. Universitas Pendidikan Indonesia

Setiawan, T. Sintaningrum. Mirandia, D. (2017). Persepsi Publik Pada Pengelolaan Taman Kota Di Kota Bandung. Universitas Padjajaran.

Sunarya, (2010). Metodologi Penelitian Model Praktis Penelitian Kuantitatif dan Kualitatif Buku Ajar Perkuliahan. Universitas Pendidikan Indonesia

Suntoro, Wongso Atmojo.(2007). Taman Kota - Solo Pos. Tentang: Penataan Ruang Terbuka Hijau (RTH) di Wilayah Perkotaan

Suyono, Bambang., Prianto, Eddy. (2017). Kajian Sensasi Kenyamanan Termal Dan Konsumsi Energi Di Taman Srigunting Kota Lama Semarang. Universitas Dipenegoro.

Vicky, T. Hajid. Nini, N. Yanuarty. Aurora .(2015). Pengunaan rumput sintetis di taman alun-alun Kota Bandung. Insititut Teknologi Bandung. https://o2indonesia.wordpress.com/2015/02/01/rumputalunalun-bdg/

Vitasari, D. Nasrullah, N. (2010). Evaluation of road greenery in three biggest settlement areas at Kabupaten Bogor, Jawa Barat. J Lansk Indonesia. 2(1):14-21.

WHO. (2016). Urban green spaces health. https://www.euro.who.int/_data/assets/pdf_file/0005/321971/Urban-green-spaces-and-h ealth-review-evidence.pdf

Zain, A. Permatasari, P. Ainya, C. Destriana, N. Mulyati, D. Edi, S. (2015). Monitoring The detection of urban open space at Jakarta, Bogor, Depok, and Tangerang-Indonesia by using remote sensing technique for urban ecology analysis. Procedia Environmental Sciences.Instiut Pertanian Bogor

Skripsi \& Tesis

Ardian, Reza Fauzi. (2016). Kajian Kebutuhan Dan Penyediaan Ruang Terbuka Hijau Publik Di Kota Bandung. Universitas Pasundan. [skripsi]

Rani Renita, 2020 
Farisatyo, Dhani. (2012). Evaluasi Program Konservasi Guna Melestarikan Kelangsungan Ekologi. Universitas Pendidikan Indonesia [skripsi]

Endah, G. (2015). Keanekaan jenis burung di Taman Kota Bandung, Jawa Barat. Universitas Padjajaran.

Hardiawan, M E. (2016). Pergeseran Fungsi Bentuk Dan Tatanan Alun-Alun Dari Masa Tradisional Hingga Modern (studi kasus: Alun-alun Kota Bandung). Universitas Komputer Indonesia. [skripsi]

Harwafi. Iman, (2013). Kajian Konsep Pengembangan "Green Corridor” Dalam Rangka Menanggulangi Pencemaran Udara Akibat Kendaraan Bermotor Pada Koridor Jalan Buah Batu Kota Bandung. Universitas Pasundan. [Tugas akhir]

Hidayat, I. W. (2008). Evaluasi Jalur Hijau Jalan Sebagai Penyangga Lingkungan Sekitarnya dan Keselamatan Pengguna Jalan Bebas Hambatan Jagorawi. Bogor (ID): Institut Pertanian Bogor. [Tesis].

Lestari, Riri Indah. (2015). Evaluasi Pemanfaatan Fungsi Taman Tematik Sebagai Urban Landscape Dalam Upaya Perwujudan Green City (Studi Kasus Taman Tematik Di Kota Bandung). Universitas Komputer Indonesia [Skripsi]

Muzdalifah, Aji Uhfatun. (2019). "Kajian Indeks Vegetasi Pada Taman Kota Semarang Dengan Pemanfaatan Citra Landsat". Universitas Diponegoro. [Tesis].

Nurbaya, A. (2015). Distribusi Tipologi Kepemilikan RTH DKI Jakarta Menggunakan Teknik Remote Sensing Citra Satelit Resolusi Tinggi. Institut Pertanian Bogor [Tesis].

Nurnovita, C. 2011. Evaluasi Fungsi Ekologis Pohon Pada RTH Lansekap Permukiman Sentul City Bogor. Institut Pertanian Bogor. [Skripsi]

Partasasmita R. (2009). "Komunitas Burung Pemakan Buah di Panaruban, Subang: Ekologi Makan dan Penyebaran Biji Tumbuhan Semak. Institut Pertanian Bogor”. Bogor. [Disertasi].

Sahid. (2016). Kajian Ruang Terbuka Hijau dan Pemenuhan Kebutuhan Oksigen Di Kampus Universitas Pendidikan Indonesia (UPI) Bandung. Universitas Pendidikan Indonesia. . [Skripsi]

Rani Renita, 2020

EVALUASI FUNGSI EKOLOGIS PADA TAMAN-TAMAN KOTA DI KOTA BANDUNG

Universitas Pendidikan Indonesia | repository.upi.edu | perpustakaan.upi.edu 
Sasongko, P.D.(2002). Kajian Perubahan Fungsi Taman Kota di Kota Semarang. Universitas Diponegoro. [Skripsi]

Segah, H. (1999). Kajian akurasi citra Landsat-TM yang didukung citra NOAA-AVHRR dalam mendeteksi perubahan penutupan lahan areal proyek pengembangan lahan gamhut (PLG) sejuta hektar di Propinsi Kalimantan Tengah. Institut Pertanian Bogor. . [Skripsi]

Setiawati, Pirka. (2012). Pengaruh Ruang Terbuka Hijau Terhadap Iklim Mikro (Studi Kasus Kebun Raya Cibodas, Cianjur). Institut Pertanian Bogor. [Skripsi]

Sulistyanto, Heri. (2017). Pemanfaatan Dan Penyediaan Ruang Terbuka Hijau Untuk Mengurangi Pencemaran Udara. Universitas Pasundan. [Skripsi]

Widyastuti, U. (2013). "Studi Keragaman Dan Fungsi Ekologis Pohon Pada Lanskap Perkampungan Budaya Betawi Setu Babakan, Srengseng Sawah, Jagakarsa, Jakarta Selatan". Institut Pertanian Bogor. [Skripsi]

Yuditia, N. (2019). Evaluasi Pemanfaatan Ruang Terbuka Hijau Sebagai Sarana Rekreasi Masyarakat Kota Bandung (Studi Kasus Taman Tematik Kota Bandung). Universitas Pendidikan Indonesia [Skripsi]

Yunus, H.S. (2008) Konsep dan Pendekatan Geografi: Memaknai Hakekat Keilmuannya. Makalah disampaikan dalam Sarasehan Forum Pimpinan Pendidikan Tinggi Geografi Indonesia pada tanggal 18-19 Januari 2008 di Fakultas Geografi UGM Yogyakarta.

Peraturan \& Perundang-undangan

Peraturan Menteri Dalam Negeri Nomor 1 Tahun 2007

Peraturan Daerah Kota Bandung Nomor 01 Tahun 2008 Tentang Pengelolaan Kawasan Konservasi Taman Tegallega.

Peraturan Pekerjaan Umum Nomor 5 Tahun 2008. Pedoman Penyediaan dan Pemanfaatan Ruang Terbuka Hijau di Kawasan Perkotaan.

Rencana Strategis Dinas Pemakaman dan Pertamanan Kota Bandung Tahun 2013 - 2018

Undang-Undang No. 26 Tahun 2007. Penataan Ruang.

Rani Renita, 2020

EVALUASI FUNGSI EKOLOGIS PADA TAMAN-TAMAN KOTA DI KOTA BANDUNG

Universitas Pendidikan Indonesia | repository.upi.edu | perpustakaan.upi.edu 
Rani Renita, 2020

EVALUASI FUNGSI EKOLOGIS PADA TAMAN-TAMAN KOTA DI KOTA BANDUNG

Universitas Pendidikan Indonesia | repository.upi.edu | perpustakaan.upi.edu 